\title{
Change in Cerebrovascular Resistance as Diagnostic Index of Cerebral Hemodynamics in Patients with Severe Combined Traumatic Brain Injury
}

DOI: $10.17691 / \mathrm{stm} 2016.8 .3 .12$

Received April 21, 2015

A.O. Trofimov, MD, PhD, Tutor, Department of Neurology, Neurosurgery and Medical Genetics";

G.V. Kalentiev, Anesthesiologist';

O.V. Voennov, MD, DSc, Professor, Department of Anesthesiology and Reanimatology";

D.S. Martynov, PhD, Senior Lecturer, Department of Computational Mathematics;

D.I. Agarkova, Tutor, Department of Eye Diseases";

V.N. Grigorieva, MD, DSc, Professor, Department of Neurology, Neurosurgery and Medical Genetics

1Nizhny Novgorod State Medical Academy, 10/1 Minin and Pozharsky Square, Nizhny Novgorod, 603005,

Russian Federation;

${ }^{2}$ N.A. Semashko Nizhny Novgorod Regional Clinical Hospital, 190 Rodionova St., Nizhny Novgorod, 603126,

Russian Federation;

${ }^{3}$ Nizhny Novgorod State Technical University named after R.E. Alekseev, 24 Minin St., Nizhny Novgorod, 603950,

Russian Federation

The aim of the investigation was to evaluate changes in cerebrovascular resistance (CVR) in severe combined traumatic brain injury (CTBI) against the background of intracranial hematoma development and its role in diagnosing the state of cerebral hemodynamics.

Materials and Methods. Treatment outcomes in 70 patients with severe CTBI (42 males and 28 females) were studied. Mean age was $35.5 \pm 14.8$ years (from 15 to 73 years). Depending on the presence of intracranial hemorrhage, the patients were divided into two groups: group 1 - without hematomas, group 2 - with hematomas. The severity of condition according to the Glasgow Coma Scale in group 1 averaged $10.4 \pm 2.6$ scores, in group 2 it was $10.6 \pm 2.8$. The severity of injuries according to ISS scale was $32 \pm 8$ and $31 \pm 11$ scores, respectively. Epidural hematomas in group 2 were revealed in 6 persons, subdural ones were found in 26, there were multiple hematomas in 4 patients. All the sufferers underwent surgery within the first three days, 30 patients $(83.3 \%)$ were operated on for hematomas during the first day.

All the patients underwent perfusion CT examination of the brain, transcranial Doppler of both middle cerebral arteries, their mean arterial pressure was measured. Relying on these data, cerebral perfusion pressure and CVR (cerebrovascular resistance) were calculated.

Results. The mean CVR values in each group (both with and without hematomas) appeared to be statistically significantly higher than the mean normal value of this parameter. Intergroup comparison of CVR values showed statistically significant increase in the CVR level in group 2 on the side of removed hematoma $(p=0.037)$. Cerebrovascular resistance in the perifocal zone of removed hematoma remained significantly higher compared to the symmetrical zone in the contralateral hemisphere $(p=0.0009)$.

Conclusion. Cerebrovascular resistance in patients with combined traumatic brain injury is significantly increased compared to the normal value and remains significantly elevated after evacuation of hematoma in the perifocal zone compared to the symmetrical zone in the contralateral hemisphere. This is indicative of certain correlation between the mechanisms of cerebral blood flow autoregulation and maintaining CVR.

Key words: combined traumatic brain injury; intracranial hematomas; cerebrovascular resistance.

Maintenance of optimal cerebral perfusion and oxygenation is one of the key aspects in management of sufferers with traumatic brain injury [1, 2]. This optimum can be determined using simultaneously several methods of evaluating cerebral macro- and microcirculation with subsequent calculation of derived indices and values [3-5]. Such approach is widely used in studying cerebral blood flow [6, 7].
The use of complex approach provides the opportunity to assess the immediate state of cerebral microcirculatory bed noninvasively [8-10], to calculate the indices of cerebral hemodynamics with high accuracy and also to determine "surrogate" secondary parameters reflecting the state of cerebral microcirculatory bed [11, 12]. One of these values is cerebrovascular resistance (CVR) [13-15].

For contacts: Aleksey O. Trofimov, e-mail: xtro7@mail.ru 
It has been established that CVR provides constant brain perfusion in conditions of changing hydrostatic and systemic arterial pressure (AP), which prevents vasogenic edema development $[16,17]$. Such CVR effect occurs within the same AP interval where the mechanisms of cerebral blood flow autoregulation operate. It speaks of definite correlation between the mechanisms of cerebral blood flow autoregulation and maintaining CVR [18].

Change in CVR occurs mainly due to changing smooth muscle tonus of the whole microcirculatory bed, namely, precapillary arterioles and true capillaries, which account for $50 \%$ of total vascular resistance $[19,20]$.

Thus, CVR reflects the status of all vascular bed components (mainly, pial bed) and is of great importance for understanding the genesis of vascular impairment in brain injuries [21, 22].

There is information that CVR growth is a premonitory sign of cerebral vasospasm and ischemia development $[7,18,23,24]$. Therefore, understanding microcirculatory bed reaction, particularly in conditions of combined traumatic brain injury (CTBI) against the background of intracranial hematoma formation, allows predicting the development of cerebral blood flow impairment.

The aim of the investigation was to evaluate changes in cerebrovascular resistance in severe combined traumatic brain injury against the background of intracranial hematoma development and its role in diagnosing the status of cerebral hemodynamics.

Materials and Methods. Hemodynamics was studied in 70 patients with severe CTBI undergoing treatment in N.A. Semashko Nizhny Novgorod Regional

Table 1

Clinical profiles of patients under study

\begin{tabular}{lcc}
\hline \multicolumn{1}{c}{ Injuries } & $\begin{array}{c}\text { Group 1 } \\
\text { (CTBI } \\
\text { without ICH) }\end{array}$ & $\begin{array}{c}\text { Group 2 } \\
\text { (CTBI } \\
\text { with ICH) }\end{array}$ \\
\hline Moderate brain contusion (II degree) & 11 & 13 \\
\hline Severe brain contusion (III degree) & 23 & 23 \\
\hline Long bone fracture & 5 & 17 \\
\hline Pelvic fracture & 6 & 4 \\
\hline Total & 34 & 36 \\
\hline
\end{tabular}

Clinical Hospital in 2011-2014. The study involved 42 males and 28 females. The patients were aged 15 to 73 years, mean age being $35.5 \pm 14.8$ years. All of them received therapy according to the international protocol, Advanced Trauma Life Support. The study complies with the Declaration of Helsinki (adopted in June 1964 (Helsinki, Finland) and revised in October 2000 (Edinburgh, Scotland)) and was approved by the Ethics Committee of N.A. Semashko Nizhny Novgorod Regional Clinical Hospital. All the patients gave informed consent to participate in the study.

Depending on the presence of intracranial hemorrhage, the patients were divided into two groups: group 1 included 34 CTBI patients without hematomas, group 2 comprised 36 sufferers with CTBI and cerebral compression due to intracranial hematomas $(\mathrm{ICH})$. Intracranial brain injuries were evaluated according to classifications of Potapov et al. [25]. The groups were comparable in age and severity of traumatic brain injury and concomitant lesions (Table 1).

The severity of condition according to the Glasgow Coma Scale in group 1 averaged $10.4 \pm 2.6$ scores, in group 2 it was $10.6 \pm 2.8$ scores.

The severity of injuries according to ISS scale (Injury Severity Score) in group 1 averaged $32 \pm 8$ and was $31 \pm 11$ scores in group 2 .

Among 36 patients of group 2 epidural hematomas were revealed in 6 persons, subdural ones were found in 26 , multiple hematomas were revealed in 4 sufferers. All hematomas were located mainly in the fronto-temporal lobes.

All the sufferers underwent surgery within the first three days. Thirty patients (83.3\%) were operated on for hematomas during the first day.

Treatment outcomes were assessed according to Glasgow Outcome Scale on discharge from hospital (Table 2).

All the patients underwent a single perfusion CT examination of the brain on 64-slice tomographic scanner, Toshiba Aquilion TSX-101A (Toshiba Medical systems, Netherlands).

In group 1 perfusion CT examination of the brain was performed within the first 14 days from the moment of getting injured (on day (4 \pm 3 ), on average), in group 2 it was done within 2-8 days after evacuation of hematomas (on day (4 \pm 2$)$, on average). All the patients breathed spontaneously, required no sedation or vasopression support.

Table 2

Distribution of patients in studied groups according to the Glasgow Outcome Scale

\begin{tabular}{lcccccc}
\hline \multicolumn{1}{c}{ Groups } & $\begin{array}{c}\text { Good recovery } \\
\text { (I degree) }\end{array}$ & $\begin{array}{c}\text { Moderate disability } \\
\text { (II degree) }\end{array}$ & $\begin{array}{c}\text { Severe disability } \\
\text { (III degree) }\end{array}$ & $\begin{array}{c}\text { Vegetative state } \\
\text { (IV degree) }\end{array}$ & $\begin{array}{c}\text { Death } \\
\text { (V degree) }\end{array}$ & $\begin{array}{c}\text { Total } \\
\text { Group 1 (CTBI without ICH) }\end{array}$ \\
\hline Group 2 (CTBI + ICH) & 15 & 10 & 6 & 2 & 1 & 34 \\
\hline
\end{tabular}


Perfusion CT examination of the brain was performed according to the following protocol. Initial unenhanced CT of the brain was carried out $[4,5]$, then 4 extended scans of $32 \mathrm{~mm}$ thick area were performed during $55 \mathrm{~s}$ against contrast medium infusion. The contrast medium (Ultravist 370; Shering AG, Germany) was infused by automatic injector (Stellant; MEDRAD Inc., USA) to the peripheral vein via a standard catheter at the rate of $5 \mathrm{ml} / \mathrm{s}$ in the dose of $50 \mathrm{ml}$ per one examination or to the central vein at the rate of $3 \mathrm{ml} / \mathrm{s}$ in the dose of $35 \mathrm{ml}$ per one examination.

After scanning the data were transferred and analyzed using standard computer program Vitrea 2 (Vital Imaging, Inc., USA, v. 4.1.8.0). "The regions of interest" were established symmetrically subcortically in the temporal lobes on the level of middle temporal gyrus, which corresponded to the vascular supply area of the middle cerebral artery. In patients of group 2 "the region of interest" located on the side of removed hematoma corresponded to the perifocal zone of microcirculatory changes.

Mean AP (mAP) was measured (Cardex MAP-03; Cardex, Russia) alongside with perfusion CT examination, on CT completion there was performed transcranial Doppler of both middle cerebral arteries (Sonomed 300M; Spectromed, Russia), which provided similar conditions for cerebral blood flow examination.

Cerebral perfusion pressure (CPP) was calculated relying on the obtained data and using the formula modified by Czosnyka [26]:

\section{$\mathrm{CPP}=\mathrm{mAP} \cdot \mathrm{Vd} / \mathrm{Vm}+14$,}

where $V d$ is diastolic cerebral blood flow velocity in the middle cerebral artery $(\mathrm{cm} / \mathrm{s}) ; V m$ is mean cerebral blood flow velocity in the middle cerebral artery $(\mathrm{cm} / \mathrm{s})$.

In this study we also calculated the values of regional cerebral blood flow (rCBF). To calculate CVR the following formula was used [27]:

$$
\mathrm{CVR}=\mathrm{CPP} / \mathrm{rCBF}
$$

where CVR was measured in $\mathrm{mm} \mathrm{Hg} \cdot 100 \mathrm{~g} \cdot \mathrm{min} / \mathrm{ml}$; CPP and $\mathrm{rCBF}$ were measured in $\mathrm{mm} \mathrm{Hg}$ and $\mathrm{ml} / 100 \mathrm{~g} \cdot \mathrm{min}$, respectively.

The mean normal CVR value (the conditional norm) was estimated according to [27] $1.54 \pm 0.24 \mathrm{~mm} \mathrm{Hg}$. $100 \mathrm{~g} \cdot \mathrm{min} / \mathrm{ml}$.

The obtained data had normal distribution, so they were presented as mean $\pm S D$. Comparison between the groups was carried out according to Student's t-test. The level of significance was taken at $p<0.05$. The results were analyzed using Statistica 7.0 software.

Results. Analysis of the studied parameters in the groups (Table 3) showed that the mean CVR values in each group of sufferers with severe CTBI (both with and without hematomas) appeared to be statistically significantly higher than the mean normal value of this parameter. Intergroup comparison of CVR values showed statistically significant increase in the CVR level in group 2 on the side of removed hematoma as compared to group $1(p=0.037)$.

The most significant differences were revealed in patients of group 2: the mean CVR index in the perifocal zone of removed hematoma remained significantly higher compared to that in the symmetrical zone of the contralateral hemisphere $(p=0.0009)$.

Besides, diastolic and mean blood flow velocity as well as CPP differed significantly in the above zones $(p=0.005 ; p=0.001$ and $p=0.0000001$, respectively)

Analysis of CVR values in various types of intracranial hematomas showed no statistically significant differences $(p>0.05)$.

Discussion. It has now been established that cerebral blood flow is in direct correlation with CPP and in negative relationship with cerebrovascular resistance $[22,28,29]$.

At the same time, CVR dynamics in brain pathology and particularly in severe combined traumatic injury remains understudied [2]. However, evaluation of CVR status is necessary since it can serve as a predictor of posttraumatic vasospasm and secondary brain damage development [7].

Table 3

Values of studied parameters in groups

\begin{tabular}{lcccccc}
\hline \multicolumn{1}{c}{ Groups } & $\begin{array}{c}\text { Mean AP } \\
(\mathrm{mm} \mathrm{Hg})\end{array}$ & Vd $(\mathrm{cm} / \mathrm{s})$ & Vm $(\mathrm{cm} / \mathrm{s})$ & $\begin{array}{c}\text { rCBF } \\
(\mathrm{ml} / 100 \mathrm{~g} \cdot \mathrm{min})\end{array}$ & $\begin{array}{c}\text { CPP } \\
(\mathrm{mm} \mathrm{Hg})\end{array}$ & $\begin{array}{c}\text { CVR } \\
(\mathrm{mm} \mathrm{Hg} \cdot 100 \mathrm{~g} \cdot \mathrm{min} / \mathrm{ml})\end{array}$ \\
\hline $\begin{array}{l}\text { Group 1 (1) } \\
\text { Group 2: on the side of former }\end{array}$ & $98.5 \pm 15.7$ & $34.0 \pm 14.2$ & $46.1 \pm 13.8$ & $31.7 \pm 10.0$ & $85.3 \pm 25.5$ & $2.94 \pm 2.20$ \\
hematoma (2) & $99.9 \pm 14.7$ & $32.5 \pm 11.5$ & $36.8 \pm 12.8$ & $32.3 \pm 17.7$ & $109.4 \pm 36.0$ & $4.06 \pm 2.16$ \\
\hline $\begin{array}{l}\text { Group 2: on the side opposite } \\
\text { to former hematoma (3) }\end{array}$ & $99.9 \pm 14.7$ & $25.5 \pm 9.9$ & $48.7 \pm 17.7$ & $28.4 \pm 11.1$ & $67.5 \pm 17.2$ & $2.7 \pm 1.1$ \\
\hline$p_{1-2}$ & 0.701 & 0.631 & 0.005 & 0.138 & 0.002 & 0.037 \\
\hline$p_{1-3}$ & 0.701 & 0.004 & 0.5 & 0.194 & 0.001 & 0.561 \\
\hline$p_{2-3}$ & 1 & 0.005 & 0.001 & 0.247 & 0.0000001 & 0.0009 \\
\hline
\end{tabular}




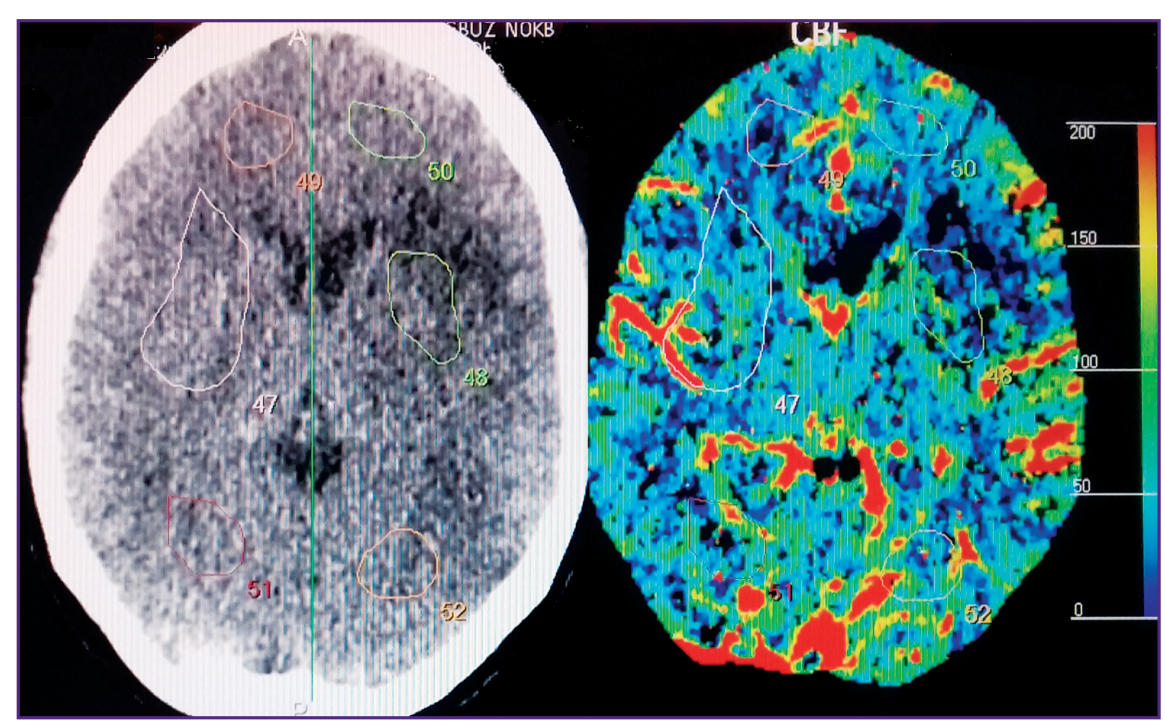

Revealing computed tomography signs of cerebral edema in a patient with combined traumatic brain injury

It has been demonstrated in our study that CVR in CTBI statistically significantly increases compared to the norm. One of the reasons for this increase is development of cytotoxic and vasogenic brain edema [30] resulting in compression of pial vessels and growth of vascular resistance. Computed tomography signs of brain edema found in all 70 patients (See Figure) indirectly confirm this hypothesis.

Another reason can be local microvascular vasospasm due to a large number of blood degradation products formed when blood gets to subarachnoid perivascular spaces. This effect results from oxidation of oxy-hemoglobin to methemoglobin with release of ferrum ions, which in their turn cause formation of superoxide radicals. Superoxides are supposed to change nitrogen oxide concentration [23] and peroxide damage to pial epithelium [31], which leads to development of microvascular vasospasm [32].

In our study transcranial Doppler revealed no signs of vasospasm in those suffered from CTBI. However, in contrast to laser Doppler flowmetry, this method does not provide the possibility to evaluate microvascular spasm, which turned to be a limitation of our investigation.

Also compression of microvasculature can develop due to astrocytic endfeet swelling in the directly adjacent to the capillary wall. Developing in the first hours after traumatic injury, it can persist during the week that follows [17, 33].

Finally, compression of pial vessels in traumatic brain injury is associated with dysfunction of pericytes, the cells embedded in the basement membrane of capillaries. It has been reported that massive narrowing of arterioles and capillaries in traumatic brain injury occurs due to impaired expression of endotellin-1 and its pericytic receptors type A and B and it is caused by migration of more than $40 \%$ of pericytes from basement membrane [34-38].

All mentioned reasons, as it was pointed out earlier, can lead to diminishing of total capillary lumen and, consequently, to CVR increase [6].

It should be noted that brain compression by intracranial hematomas changes CVR even more [39]. Thus, we have found that even after intracranial hematoma evacuation CVR in its perifocal zone remained significantly higher than in the symmetrical zone of the contralateral hemisphere.

Some researchers point out that compression of capillary system in the perifocal zone of hematoma can reach such values at which blood flow in arterioles stops. Compression value is individual and known as critical closing pressure [21]. Such situation leads to severe reduction in the number of functioning capillaries and CVR increase on the side of compression [39].

In these conditions temporary microvascular shunts open and there develop supracapillary and intracapillary shunting phenomena to maintain perfusion in the perifocal zone [40]. Probably, the development of capillary shunting syndrome explains the paradoxical result obtained in our study, when predicted CVR value on the side of removed hematoma appeared to be higher than MAP.

Thus, the obtained findings enable us to conclude that in the early stage of severe combined traumatic brain injury there occur marked changes in cerebrovascular resistance and cerebral microcirculation, which are exacerbated by development of intracranial hematomas.

Conclusion. Cerebrovascular resistance in patients with combined traumatic brain injury is significantly increased compared to the normal value. After evacuation of hematoma in the former perifocal zone cerebrovascular resistance remains significantly elevated compared to the symmetrical zone in the contralateral hemisphere. Analysis of CVR status offers the possibility to distinguish a group of patients with high risk of cerebral vasospasm and posttraumatic secondary insult development.

Study Funding and Conflicts of Interest. The study was not supported by any financial sources and there is no conflicts of interest related to the authors of this study.

\section{References}

1. Oshorov A.V., Savin I.A., Goryachev A.S., Popugaev K.A., Polupan A.A., Sychev A.A., Gavrilov A.G., 
Kravchuk A.D., Zakharova N.E., Danilov G.V., Potapov A.A. ICP plateau waves in patients with severe traumatic brain injury. Anesteziologiya i reanimatologiya 2013; 4: 44-50.

2. Furuya Y., Hlatky R., Valadka A., Diaz P., Robertson C.S. Comparison of cerebral blood flow in computed tomographic hypodense areas of the brain in head-injured patients. Neurosurgery 2003; 52(2): 340-346, http://dx.doi. org/10.1227/01.neu.0000043931.83041.aa.

3. Potapov A.A., Zakharova N.E., Pronin I.N., Kornienko V.N., Gavrilov A.G., Kravchuk A.D., Oshorov A.V., Sychev A.A., Zaĭtsev O.S., Fadeeva L.M., Takush S.V. Prognostic value of ICP, CPP and regional blood flow monitoring in diffuse and focal traumatic cerebral lesions. Voprosy neyrokhirurgii im. N.N. Burdenko 2011; 75(3): 3-18.

4. Etminan N., Hänggi D. Perfusion CT imaging as a radiological surrogate for early brain injury - summary of current data on aneurysmal subarachnoid hemorrhage (Part A). In: Brain Edema 2014. The 16th International Conference on Brain Edema and Cellular Injury. The 3rd International Conference on Preconditioning for Neurological Disorders. Huntington Beach, California; September 27-30, 2014. URL: http://brainedema2014.com/program_outline. html.

5. Hattingen E., Blasel S., Dumesnil R., Vatter H., Zanella F.E., Weidauer S. MR angiography in patients with subarachnoid hemorrhage: adequate to evaluate vasospasminduced vascular narrowing? Neurosurg Rev 2010; 33(4): 431439, http://dx.doi.org/10.1007/s10143-010-0267-4.

6. Ursino M., Lodi C.A. A simple mathematical model of the interaction between intracranial pressure and cerebral hemodynamics. J Appl Physiol 1997; 82(4): 1256-1269.

7. Westermaier T., Pham M., Stetter C., Willner N., Solymosi L., Ernestus R.I., Vince G.H., Kunze E. Value of transcranial Doppler, perfusion-CT and neurological evaluation to forecast secondary ischemia after aneurysmal SAH. Neurocrit Care 2014; 20(3): 406-412, http://dx.doi.org/10.1007/ s12028-013-9896-0.

8. Aries M. Cerebral hemodynamics in stroke and traumatic brain injury: the interplay between blood pressure, cerebral perfusion, body position and autoregulation. Doctoral Dissertation. Gröningen, The Netherlands; 2012.

9. Avezaat C.J.J., Eijndhoven J.H.M. Cerebrospinal fluid pulse pressure and craniospatial dynamics. A theoretical, clinical and experimental study. Erasmus University, Rotterdam; 1984.

10. Rhee C., Kibler K., Easley R., Andropulos D., Czosnyka M., Smielewski P., Vorsos G., Brady K., Rusin C., Kaiser J. The ontogeny of cerebral blood flow autoregulation and critical closing pressure. In: The 15th International Conference on Intracranial Pressure and Brain Monitoring. Singapore; November 6-10, 2013; p. 66.

11. Heldt T., Noraky J., Verghese G. Noninvasive intracranial pressure determination in patients with subarachnoid hemorrhage. In: The 15th International Conference on Intracranial Pressure and Brain Monitoring. Singapore; November 6-10, 2013; p. 40.

12. Kapinos G., Sadoughi A., Narayan R. Intracranial pressure treatment tailored to transcranial Doppler-derived compliance and perfusion. In: The 15th International Conference on Intracranial Pressure and Brain Monitoring. Singapore; November 6-10, 2013; p. 44.

13. Dewey R., Pierer H., Hunt W. Experimental cerebral hemodynamics. Vasomotor tone, critical closing pressure, and vascular bed resistance. J Neurosurg 1974; 41(5): 597-606, http://dx.doi.org/10.3171/jns.1974.41.5.0597.

14. Kasprowicz M. Badania hemodynamiki mózgowej na podstawie analizy pulsacji ciśnienia wewnątrzczaszkowego, ciśnienia tętniczego i przepływu krwi mózgowej [Assessment of cerebral hemodynamics based on pulse waveform analysis of intracranial pressure, arterial blood pressure and cerebral blood flow]. Oficyna Wydawnicza Politechniki Wrocławskiej. Wrocław; 2012.

15. Kasprowicz M., Diedler J., Reinhard M., Carrera E., Steiner L.A., Smielewski P., Budohoski K.P., Haubrich C., Pickard J.D., Czosnyka M. Time constant of the cerebral arterial bed in normal subjects. Ultrasound Med Biol 2012; 38(7): 1129-1137, http://dx.doi.org/10.1016/j. ultrasmedbio.2012.02.014.

16. Laan ter Mark. Neuromodulation of cerebral blood flow. PhD Dissertation. Gröningen, The Netherlands; 2014.

17. Narayanan N., Leffler C.W., Czosnyka M., Daley M.L. Assessment of cerebrovascular resistance with model of cerebrovascular pressure transmission. Acta Neurochir Suppl 2008; 102: 37-41, http://dx.doi.org/10.1016/j. medengphy.2008.07.002.

18. Sharples P.M., Matthews D.S., Eyre J.A. Cerebral blood flow and metabolism in children with severe head injuries. Part 2: cerebrovascular resistance and its determinants. J Neurol Neurosurg Psychiatry 1995; 58(2): 153-159, http:// dx.doi.org/10.1136/jnnp.58.2.153.

19. Daley M., Narayanan N., Leffler C. Model-derived assessment of cerebrovascular resistance and cerebral blood flow following traumatic brain injury. Exp Biol Med (Maywood) 2010; 235(4): 539-545, http://dx.doi.org/10.1258/ ebm.2010.009253.

20. Smirl J.D., Tzeng Y.C., Monteleone B.J., Ainslie P.N. Influence of cerebrovascular resistance on the dynamic relationship between blood pressure and cerebral blood flow in humans. J Appl Physiol 2014; 116(12): 1614-1622, http:// dx.doi.org/10.1152/japplphysiol.01266.2013.

21. Bragin D.E., Bush R.C., Müller W.S., Nemoto E.M. High intracranial pressure effects on cerebral cortical microvascular flow in rats. J Neurotrauma 2011; 28(5): 775-785, http://dx.doi. org/10.1089/neu.2010.1692.

22. Muizelaar J.P., Marmarou A., DeSalles A.A., Ward J.D., Zimmerman R.S., Li Z., Choi S.C., Young H.F. Cerebral blood flow and metabolism in severely head-injured children. Part 1: relationship with GCS score, outcome, ICP, and PVI. J Neurosurg 1989; 71(1): 63-71, http://dx.doi.org/10.3171/ jns.1989.71.1.0063.

23. Pluta R.M. Delayed cerebral vasospasm and nitric oxide: review, new hypothesis, and proposed treatment. Pharmacol Ther 2005; 105(1): 23-56, http://dx.doi. org/10.1016/j.pharmthera.2004.10.002.

24. Siemkowicz E. Cerebrovascular resistance in ischemia. Pflügers Archiv 1980; 388(3); 243-247, http://dx.doi. org/10.1007/bf00658489.

25. Potapov A.A., Zakharova N.E., Kornienko V.N., Pronin I.N., Aleksandrova E.V., Zaĭtsev O.S., Likhterman L.B., Gavrilov A.G., Danilov G.V., Oshorov A.V., Sychev A.A., Polupan A.A. Neuroanatomical basis for traumatic coma: clinical and magnetic resonance correlates. Voprosy neyrokhirurgii im. N.N. Burdenko 2014; 78(1): 4-13.

26. Czosnyka M., Smielewski P., Kirkpatrick P., Laing R.J., Menon D., Pickard J.D. Continuous assessment of the cerebral vasomotor reactivity in head injury. Neurosurgery 1997; 
41(1): 11-19, http://dx.doi.org/10.1097/00006123-19970700000005.

27. Scheinberg P., Stead E. The cerebral blood flow in male subjects as measured by the nitrous oxide technique. Normal values for blood flow, oxygen utilization, glucose utilization, and peripheral resistance, with observations on the effect of tilting and anxiety. J Clin Invest 1949; 28(5): 1163-1171, http:// dx.doi.org/10.1172/jci102150.

28. Lassen N.A. Autoregulation of cerebral blood flow. Circ Res 1964; 15(Suppl): 201-204.

29. Marmarou A. A review of progress in understanding the pathophysiology and treatment of brain edema. Neurosurg Focus 2007; 22(5): E1, http://dx.doi.org/10.3171/ foc.2007.22.5.2.

30. Cernak I., Vink R., Zapple D.N., Cruz M.I., Ahmed F., Chang T., Fricke S.T., Faden A.I. The pathobiology of moderate diffuse traumatic brain injury as identified using a new experimental model of injury in rats. Neurobiol Dis 2004; 17(1): 29-43, http://dx.doi.org/10.1016/j.nbd.2004.05.011.

31. Rey F.E., Li X.C., Carretero O.A., Garvin J.L., Pagano P.J. Perivascular superoxide anion contributes to impairment of endothelium-dependent relaxation: role of gp91(phox). Circulation 2002; 106(19): 2497-2502, http:// dx.doi.org/10.1161/01.cir.0000038108.71560.70.

32. Østergaard L., Engedal T.S., Aamand R., Mikkelsen R., Iversen N.K., Anzabi M., Næss-Schmidt E.T., Drasbek K.R., Bay V., Blicher J.U., Tietze A., Mikkelsen I.K., Hansen B., Jespersen S.N., Juul N., Sørensen J.C., Rasmussen M. Capillary transit time heterogeneity and flow-metabolism coupling after traumatic brain injury. J Cereb Blood Flow Metab 2014; 34(10): 1585-1598, http://dx.doi.org/10.1038/ jcbfm.2014.131.

33. Bullock R., Maxwell W.L., Graham D.I., Teasdale G.M., Adams J.H. Glial swelling following human cerebral contusion: an ultrastructural study. J Neurol Neurosurg Psychiatry
1991; 54(5): 427-434, http://dx.doi.org/10.1136/jnnp.54.5.427.

34. Armulik A., Genové G., Mäe M., Nisancioglu M.H., Wallgard E., Niaudet C., He L., Norlin J., Lindblom P., Strittmatter K., Johansson B.R., Betsholtz C. Pericytes regulate the blood-brain barrier. Nature 2010; 468(7323): 557-561, http://dx.doi.org/10.1038/nature09522.

35. Dore-Duffy P., Wang S., Mehedi A., Katyshev V., Cleary K., Tapper A., Reynolds C., Ding Y., Zhan P., Rafols J., Kreipke C.W. Pericyte-mediated vasoconstriction underlies TBI-induced hypoperfusion. Neurol Res 2011; 33(2): 176-186, http://dx.doi.org/10.1179/016164111x12881719352372.

36. Hall C.N., Reynell C., Gesslein B., Hamilton N.B., Mishra A., Sutherland B.A., O'Farrell F.M., Buchan A.M., Lauritzen M., Attwell D. Capillary pericytes regulate cerebral blood flow in health and disease. Nature 2014; 508(7494): 55 60, http://dx.doi.org/10.1038/nature13165.

37. Kreipke C.W., Schafer P.C., Rossi N.F., Rafols .A. Differential effects of endothelin receptor $A$ and $B$ antagonism on cerebral hypoperfusion following traumatic brain injury. Neurol Res 2010; 32(2): 209-214, http://dx.doi. org/10.1179/174313209x414515.

38. Yemisci M., Gursoy-Ozdemir Y., Vural A., Can A., Topalkara K., Dalkara T. Pericyte contraction induced by oxidative-nitrative stress impairs capillary reflow despite successful opening of an occluded cerebral artery. Nat Med 2009; 15(9): 1031-1037, http://dx.doi.org/10.1038/nm.2022.

39. Vollmar B., Westermann S., Menger M.D. Microvascular response to compartment syndrome-like external pressure elevation: an in vivo fluorescence microscopic study in the hamster striated muscle. J Trauma 1999; 46(1): 91-96, http:// dx.doi.org/10.1097/00005373-199901000-00015.

40. Bragin D., Bush R., Nemoto E. Effect of cerebral perfusion pressure on cerebral cortical microvascular shunting at high intracranial pressure in rats. Stroke 2013; 44(1): 177181, http://dx.doi.org/10.1161/STROKEAHA.112.668293. 